\title{
ROLE OF COMPUTATIONAL SIMULATIONS IN THE DESIGN OF PISTON RINGS
}

\author{
PAVEL NOVOTNÝ, PETER RAFFAI, JOZEF DLUGOŠ, ONDŘEJ MARŠÁLEK, JIŘÍ KNOTEK
}

Brno University of Technology, Technická 2, CZ 61669 Brno, Czech Republic, Tel.: +420 541142 272, Fax: +420 541143354

Email: novotny.pa@fme.vutbr.cz

\begin{abstract}
SHRNUTí
Článek prezentuje výpočtové přistupy založené na soudobých strategiích řešení dynamiky pístních kroužků jako strukturálně tekutinový problém. Výstupy těchto výpočtových modelů Ize využít k hlubšímu porozumění vlivu jednotlivých konstrukčních parametrů pístních kroužků na vybrané výsledky většinou integrálního charakteru. Řešení dynamiky pístních kroužků zahrnuje podmínky smíšeného mazání, vliv nerovností na proudění v olejové vrstvě, vliv pohybu kroužků na dynamiku plynů, tvorbu olejové vrstvy na vložce válců a další podstatné vlivy. Výsledky řešení jsou prezentovány na vybraných parametrech pístních kroužků zážehového motoru.

KLIČCVÁ SLOVA: SMIIŚENÉ MAZÁNÍ, PÍSTNII KROUŽEK, PARAMETRICKÁ STUDIE, TVORBA OLEJOVÉ VRSTVY

\section{ABSTRACT}

The paper presents computational approaches using modern strategies for a dynamic piston ring solution as a fluid structural problem. Computational model outputs can be used to understand design parameter influences on defined results of a primarily integral character. Piston ring dynamics incorporates mixed lubrication conditions, the influence of surface roughness on oil film lubrication, the influence of ring movement on gas dynamics, oil film formulation on a cylinder liner and other significant influences. The solution results are presented for several parameters of $S I$ engine piston rings.
\end{abstract}

KEYWORDS: MIXED LUBRICATION, PISTON RING, PARAMETRIC STUDY, OIL FILM FORMULATION

\section{INTRODUCTION}

The piston assembly is a key component of an internal combustion engine (ICE). The performance of piston assembly components play an important role in many generally known areas. Current state-of-the-art ICEs demonstrate a high level of technical sophistication, and therefore the design of any ICE provides a significant opportunity for the utilization of modern computational and experimental approaches.

Mechanical losses and oil consumption are among the most important integral criteria of piston ring design. Mechanical losses of an ICE due to the friction between the engine components account for between 4 and $15 \%$ of the total energy consumed in modern combustion engines during typical driving cycles $[2,3,4]$. Depending on the ICE, the mechanical loss accounted for by the piston assembly can be estimated very approximately as half of the total mechanical losses. More than half of this is generated by the piston rings. Therefore, the reduction of piston ring friction has the potential to improve ICE efficiency, fuel consumption and reduce emissions of $\mathrm{CO}_{2}$.
Friction loss studies of piston ring pack problems are covered by a large volume of international literature. The list of various physical effects includes piston ring geometry effects, gas dynamics, ring dynamics, lubrication and oil availability, surface treatment, lubricant rheology and changes in its chemistry.

Relatively simple models which include analytical-empirical lubrication solutions, or even that of piston ring dynamics, can be used in a limited way for approximate determination of friction losses. These models are often calibrated using technical experiments, and they are only usable on ICEs with the same cylinder unit. They can be applied mainly in studies of conceptual design of new power units, where considerable computational speed is required. An example of such models can be found, for instance, in Macek [6].

Another group of computational models is represented by numerical models based on the separate solution of a piston ring, or the whole pack of piston rings, using inputs from 3D (3-dimensional) computer models of powertrains, mostly based on multi-body systems [7]. The ring is mainly considered a point 
mass, and equations describing the dynamics and lubrication are often formulated as 2D (2-dimensional). These approaches enable very complex computational models, while conserving reasonable computational times. The use of these approaches is presented by, for instance, Novotný [1], Arcoumanis [8], Mufti [9] and Wannatong [10].

The most time-consuming approach for dealing with the piston assembly is the use of 3D FEM methods, mainly on the basis of commercial tools in combination with some improvements. The ring is formulated as a 3D elastic body and the model almost always contains a piston and its influence on the piston rings. These computational approaches can provide very detailed results, but their solution is currently very time-consuming in terms of the model preparation and its calculation. For this reason in particular, they are not suitable for large parametric studies. Ortjohann in his work [11] presents a complete model of a piston pack assembly in an explicit solver of the commercial software ABAQUS, adding partial computational models through user subroutines. Other similar approaches can be found, for example, in $[12,13,14]$.

\section{AIM OF THE WORK}

The main objective of this work is to develop computational models and algorithms for a piston ring pack, capable of supporting the design of new piston rings with lower friction losses. The main emphasis is not put on the accurate determination of the power losses, but on determination of the influence of various design parameters of the rings. Numerical solutions of the proposed computational models must be very efficient, so that it is possible to

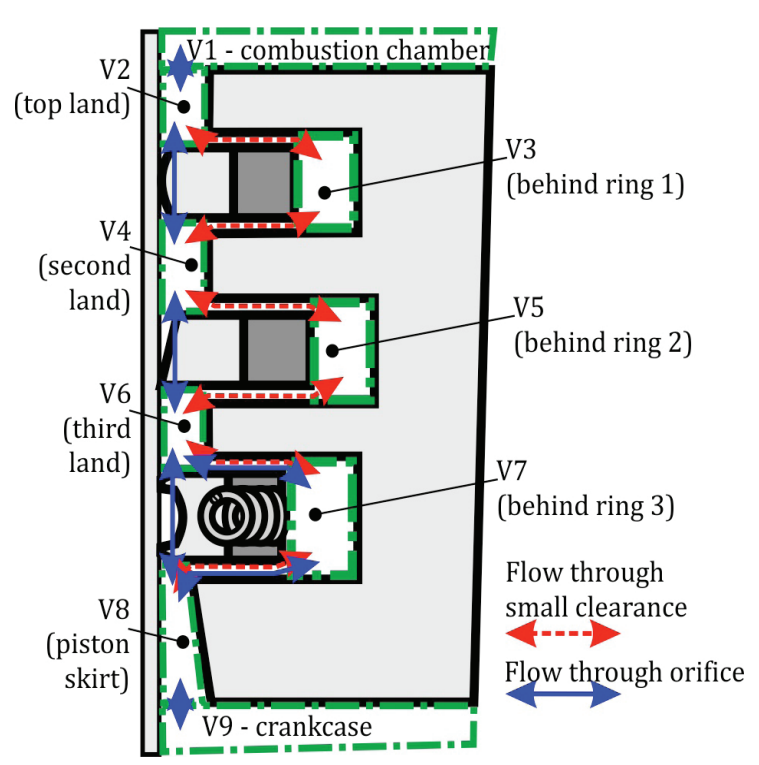

FIGURE 1: Blow-by/blow-back flow model scheme OBRÁZEK 1: Schéma modelu profuku plynů

perform parametric studies. However, computational models must not suffer too much in terms of quality due to the simplification of the description or the neglect of various physical problems.

\section{THEORETICAL ASSUMPTIONS}

\subsection{GAS BLOW-BY AND BLOW-BACK}

A solution of gas flows through the piston assembly requires the dividing of the system into several groups. The gas flow through the piston ring pack is presumed to be isentropic, including:

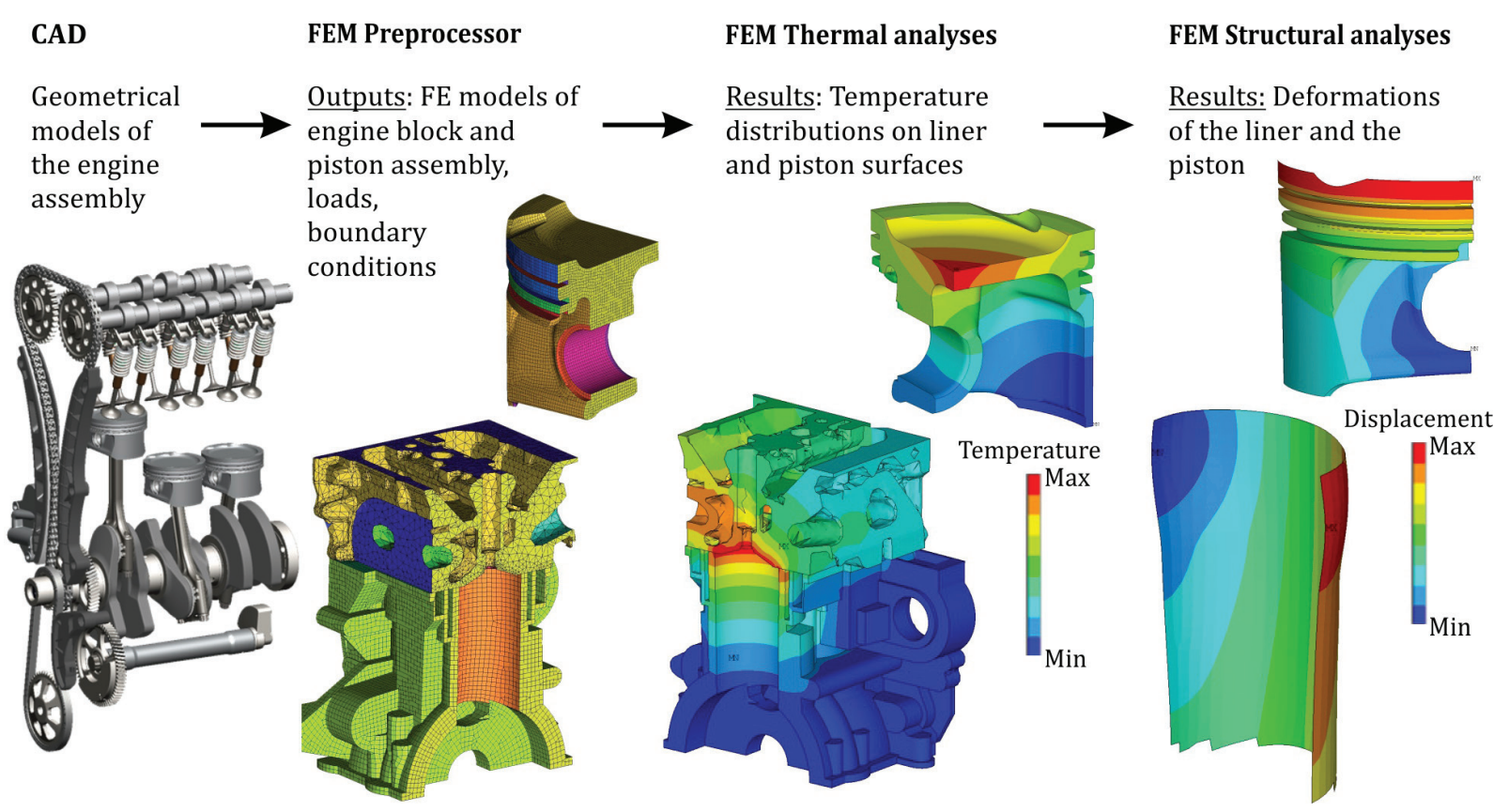

FIGURE 2: Computational steps for determining the piston and cylinder liner deformation and temperature OBRÁZEK 2: Výpočtové kroky pro stanovení rozložení teplot a deformací vložky válce a pístu 
- Flow through the piston ring gap

- Flow between the piston ring and the piston groove

- Flow between the piston ring and the cylinder liner

The volumes of the chambers are determined with respect to the operating deformation of the piston and the cylinder liner. In order to solve operational deformations caused by operating temperature and combustion pressure, a detailed FE model of the piston and the engine block is developed. In the first step the computational models are used to solve the temperature distribution. Boundary conditions include heat transfer coefficients of individual parts, and the heat flux generated by fuel combustion. Individual values are determined experimentally on a similar engine. Figure 2 presents the procedure for calculation of the cylinder liner and piston deformation.

This flow model presumes the gas flow through the piston ring gap to be an isentropic orifice flow between two volumes. In the case of gas flow through a small clearance between the ring and the piston groove a one-dimension Reynolds equation is used to calculate the mass flow, assuming the flow to be laminar.

The result of the FE solution is the average deformation of the cylinder liner and the piston, and the corresponding values of the volumes required for the solution of gas blowing.

The flow described by a system of differential equations is solved numerically incorporating a predictor-corrector method (AdamsBashforth and Adams-Moulton). The influence of piston ring movements are also considered in the solution.

\subsection{HYDRODYNAMIC LUBRICATION}

If some amount of oil is present between the ring and the liner, hydrodynamic lubrication can be considered. The given problem is described by the Reynolds equation, which defines the relationship between the lubricant pressure and the lubricant film shape. The Reynolds equation can be simplified by assumptions of constant viscosity and density. The lubricant film thickness between the piston ring and the liner is presumed to be much smaller than the piston ring radius. Then the hydrodynamic problem can be solved as an infinite flat bearing. The Reynolds equation can be averaged and simplified to an ordinary differential equation $[8,10]$.

At low speeds in particular, the oil film thickness is very small and it can achieve the size of the surface roughness. The influence of surface roughness on hydrodynamic lubrication can be included by using the shear factor $[15,16]$. The resulting form of the Reynolds equation is then

$$
\frac{d}{d x}\left(\phi_{x} \frac{h^{3}}{12 \eta} \frac{d p_{A}}{d x}\right)=\frac{U}{2} \frac{d h_{T A}}{d x}+\frac{U}{2} \sigma_{C} \frac{d \phi_{s}}{d x}+\frac{d h_{T A}}{d t} .
$$

Where $x$ is the coordinate in cylinder axis direction, $p_{A}$ is the circumferential averaged pressure, $h$ is the nominal oil film thickness, $h$ is the dynamic viscosity of oil, $h_{T A}$ is the local oil film thickness, $F_{x}$ is the pressure flow factor, $F_{s}$ shear flow factor, $s_{c}$ is the standard deviation of combined roughness and $U$ represents piston velocity. To simplify the writing and to improve the numerical solution of equation (1) the following variables can be used

$$
\begin{aligned}
& H=h / \sigma_{C} \quad X=x / \sigma_{C} \\
& H_{T}=h_{T A} / \sigma_{C} \quad P=p_{A} \sigma_{C} \\
& \theta=t U /\left(2 \sigma_{C}\right) \quad \xi=\phi_{x} H^{3} /(6 \eta U)
\end{aligned}
$$

Symbol $H$ denotes a dimensionless thickness of the oil gap and $H_{T}$ is the average dimensionless thickness of the oil gap. Using equations (2), equation (1) can be written in the following form

$$
\frac{d}{d X}\left(\xi \frac{d P}{d X}\right)=\frac{d H_{T}}{d X}+\frac{d \phi_{s}}{d X}+\frac{d H_{T}}{d \theta} .
$$

For the discretization of equation (3) the finite difference method is used and for numerical solution the Gauss-Seidel method supplemented by strategies to accelerate the calculation is used. Numerical solution of equation (3) is supplemented by a simplified model of cavitation corresponding to Reynolds cavitation conditions. This is done so that at the time of the negative pressure creation, the pressure is set to point zero at a given site. Boundary conditions are set so that the oil pressure at the edge of the ring corresponds to the gas pressure at the site.

\subsection{BOUNDARY LUBRICATION}

Pure boundary lubrication according to Greenwood and Tripp [17] is used when oil supply is insufficient. This classical approach requires input data based on measurement of surface quantities of real components. The use of a surface generator based on a typical machining processes can optionally be used as presented by Maršálek [18].

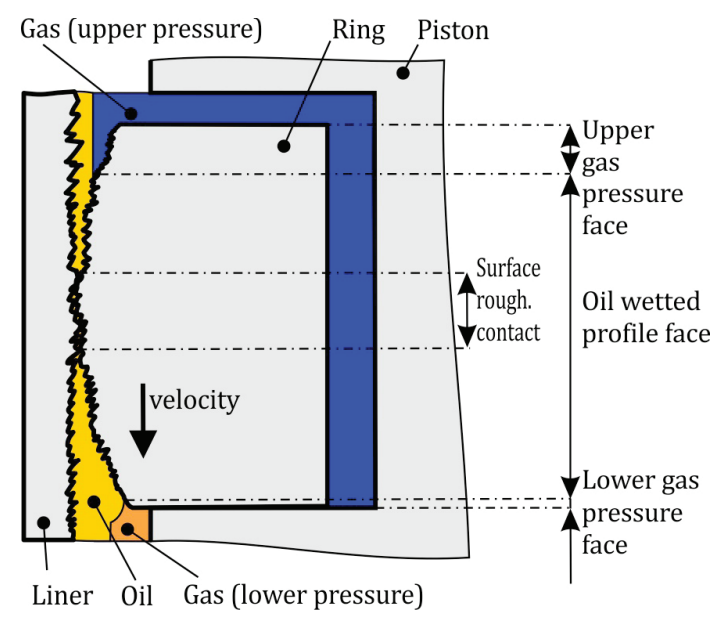

FIGURE 3: Region description of the piston ring-liner subsystem OBRÁZEK 3: Popis oblastí subsystému pístní kroužek a vložka válce 


\subsection{OIL FILM FORMULATION}

The amount of oil on the cylinder liner is a key issue for more accurate solution of mixed lubrication.

The basic assumption is based on the idea that the amount of oil over the scraper ring is unchanged (see Figure 4).

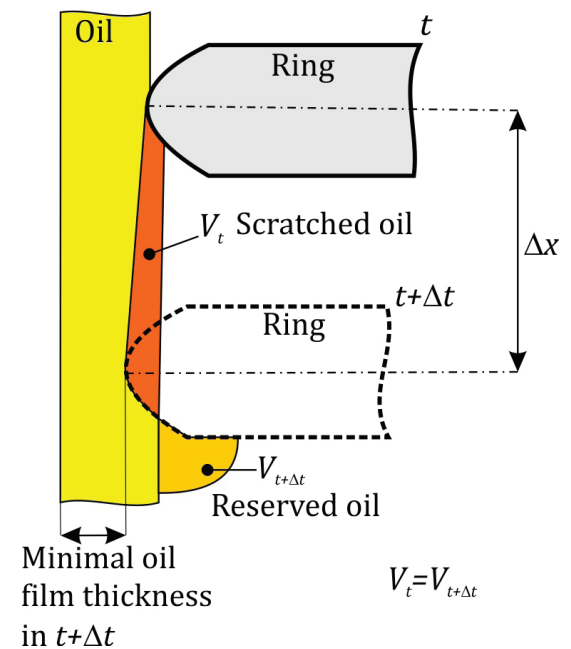

FIGURE 4: The basic assumption for amount of oil scrapped by ring OBRÁZEK 4: Základní předpoklady pro množství kroužkem setřeného oleje

This assumption is not entirely accurate, because the operation of the motor leads to various mechanisms affecting the amount of oil, such as the burning of oil in the working area or adhesion of oil to the piston.

\subsection{NUMERICAL SCHEME}

For each ring the force balance is solved at a given time. The following forces are considered for the solution:

- Inertia forces.

- Ring preload forces.

- Gas pressure forces.

- Forces due to asperity contacts between the ring and cylinder liner.

- Radial hydrodynamic forces between the ring and cylinder liner.

- Radial contact forces between the ring and piston.

Solving the balance of forces on the ring is influenced significantly by the speed of solving the nonlinear problem. In this work a modified Newton Raphson method with predictor is used.

\section{STRATEGIES FOR REDUCTION OF PISTON RING FRICTION LOSSES}

The following chapter contains a description of selected strategies appropriate for reducing friction losses of a piston ring pack of an inline three-cylinder gasoline engine. The basic engine parameters are presented in Table 1.

\begin{tabular}{lc} 
Engine & \\
\hline Bore & $76,5 \mathrm{~mm}$ \\
\hline Stroke & $86,9 \mathrm{~mm}$ \\
\hline Displacement & $1198 \mathrm{~cm}^{3}$ \\
\hline Compression ratio & 10,5 \\
\hline Nominal power & $51 \mathrm{~kW}$
\end{tabular}

TABLE 1: Target engine basic parameters

TABULKA 1: Základní parametry modelovaného motoru

The potential of each design strategy is verified by calculation using the developed computational models. The project included many parameters presumed to have an effect on the required quantities for all piston rings. Due to the broad scope of the results, only a few selected effects are presented in this article.

\subsection{TOP RING}

Friction losses of the first compression ring are primarily affected by the result of high combustion pressures near TDC (Top Dead Center). The resulting forces are often greater by several orders of magnitude than the tangential force from the ring prestressing. Therefore, appropriate structural variants tend to limit this effect, thus reducing the pressure difference on the inner and outer perimeter of the ring.

The basic modification to the first barrel face seal ring is its profile asymmetry. The influence of the first ring profile asymmetry on the power losses of individual rings for an engine speed of 5000 rpm is shown in Figure 5. The second ring and the oil control ring (OCR) are also unaffected by profile asymmetry. From the results it is clear that the asymmetry of the first piston ring affects mainly the friction losses due to the reduced contact between the peaks of asperities. The hydrodynamic part of the friction losses is not affected much by the asymmetry of the first ring. Figure 6 summarizes the simulation results for the entire range of operating speeds.

\subsection{SECOND RING}

There are several changes to the second ring shape that can affect different properties. Different shapes of ring profile or ring preload might be chosen. One of the parameters affecting the friction loss and the amount of oil on the cylinder liner is the angle of the working surface, and further in this article this single effect is considered. The impact of this adjustment on the power losses of the individual rings for an engine speed of 5000 rpm is presented in Figure 7.

The results show that by increasing the angle of the working area, the bearing area of the ring is reduced, thus the proportion of asperity contact increases, which in turn increases friction losses.

\section{CONCLUSION}

The results achieved from all the computational work suggest several possible redesigns of the piston rings that would allow for 

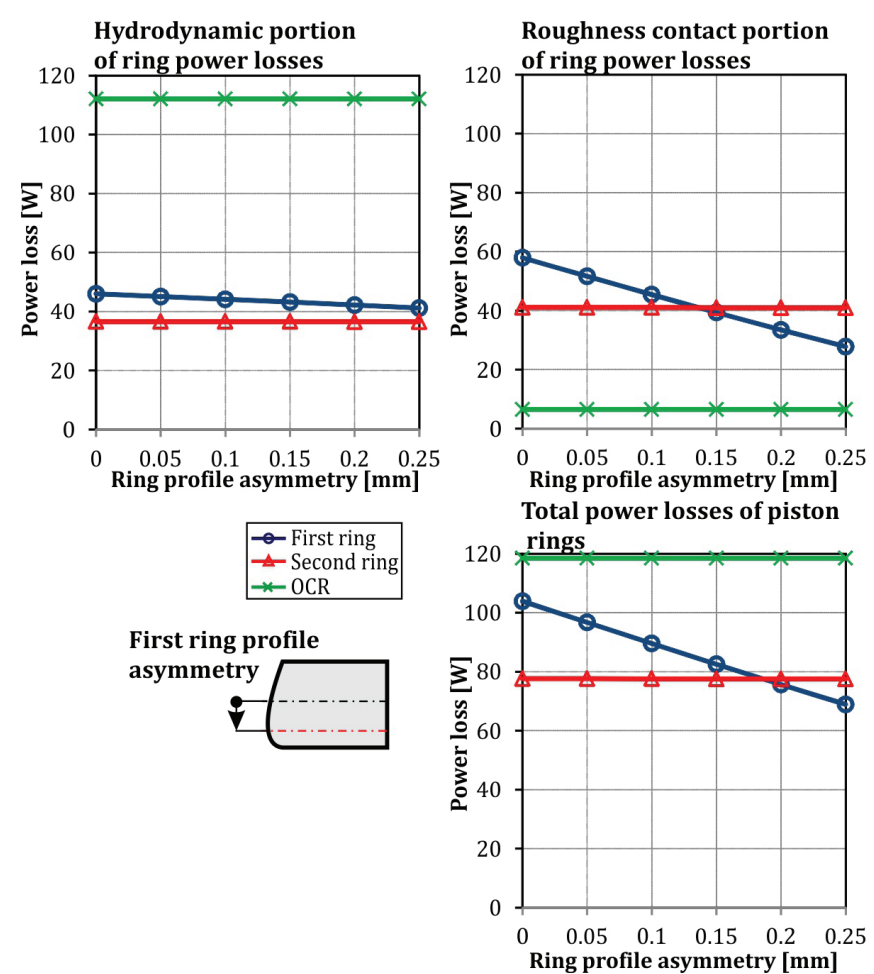

FIGURE 5: Influence of the first ring profile asymmetry on friction losses for engine speed $5000 \mathrm{rpm}$

OBRÁZEK 5: Vliv asymetrie profilu prvního kroužku na třecí ztráty pro otáčky motoru $5000 \mathrm{~min}^{-1}$

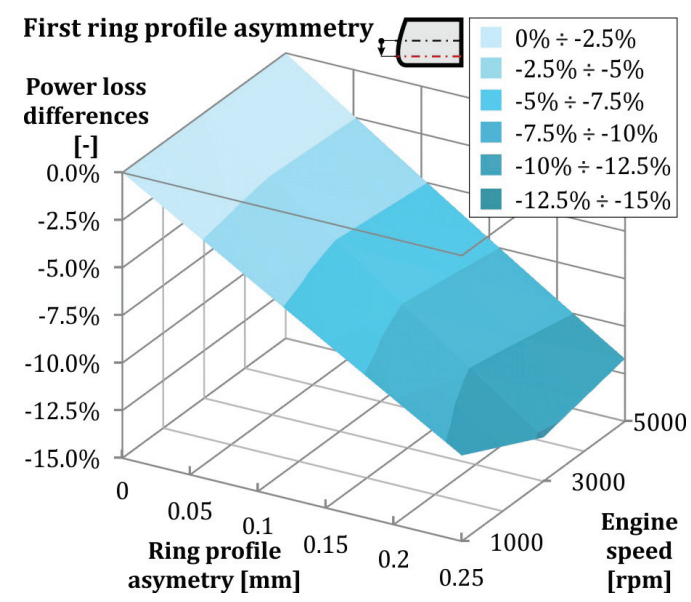

FIGURE 6: Influence of the first ring profile asymmetry

on its friction losses

OBRÁZEK 6: Vliv asymetrie profilu prvního kroužku na třecí ztráty

further improvement of the technical and economic parameters of piston rings, and hence modern internal combustion engines. The simulation results not only recommend possible options to reduce friction losses, but also offer recommendations on how to modify the manufacturing tolerances in order to reduce the cost of ring production.
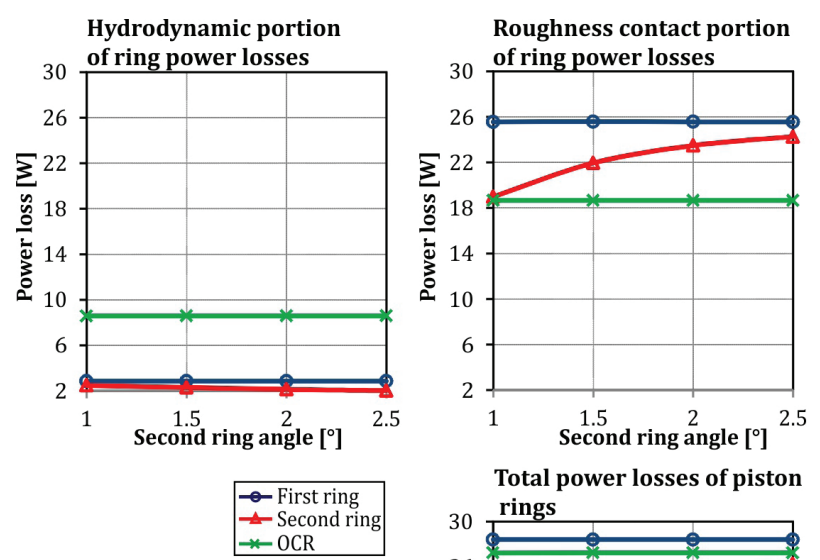

Total power losses of piston

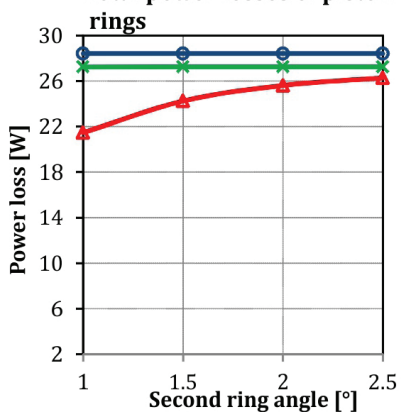

FIGURE 7: Influence of the working profile angle of the second piston ring on friction losses for engine speed $5000 \mathrm{rpm}$

OBRÁZEK 7: Vliv úhlu pracovní plochy druhého kroužku na třecí ztráty pro otáčky motoru $5000 \mathrm{~min}^{-1}$

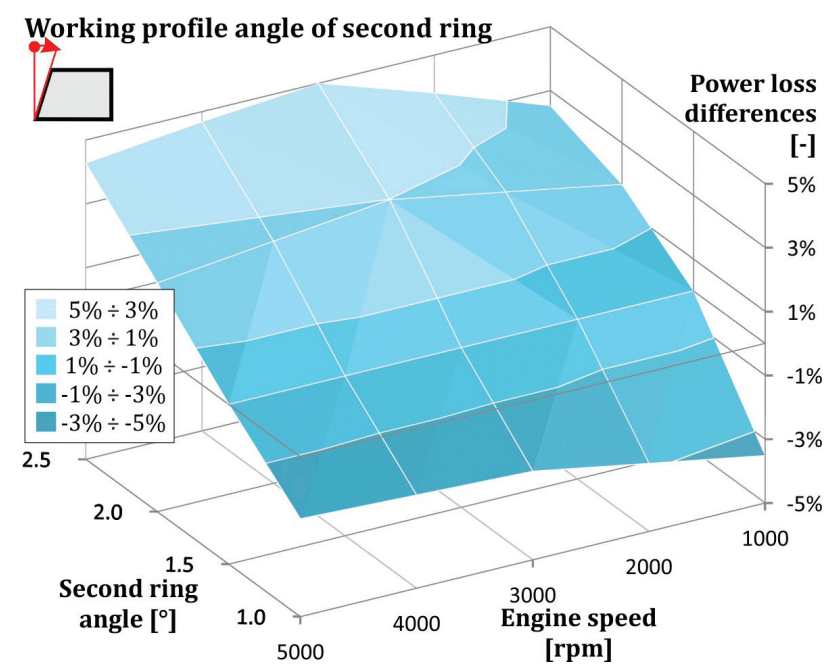

FIGURE 8: Influence of the working profile angle of the second piston ring on its friction losses

OBRÁZEK 8: Vliv úhlu pracovní plochy druhého kroužku na třecí ztráty

The selected results were confirmed using appropriate technical experiments enabling correction of the potential parameters of the calculation model. Logically, it is not possible to verify all the available results, but this fact may not be crucial, since the aim is not, for instance, to determine the precise power loss of a piston ring. It is essential to determine the tendency with the change of selected parameters. 


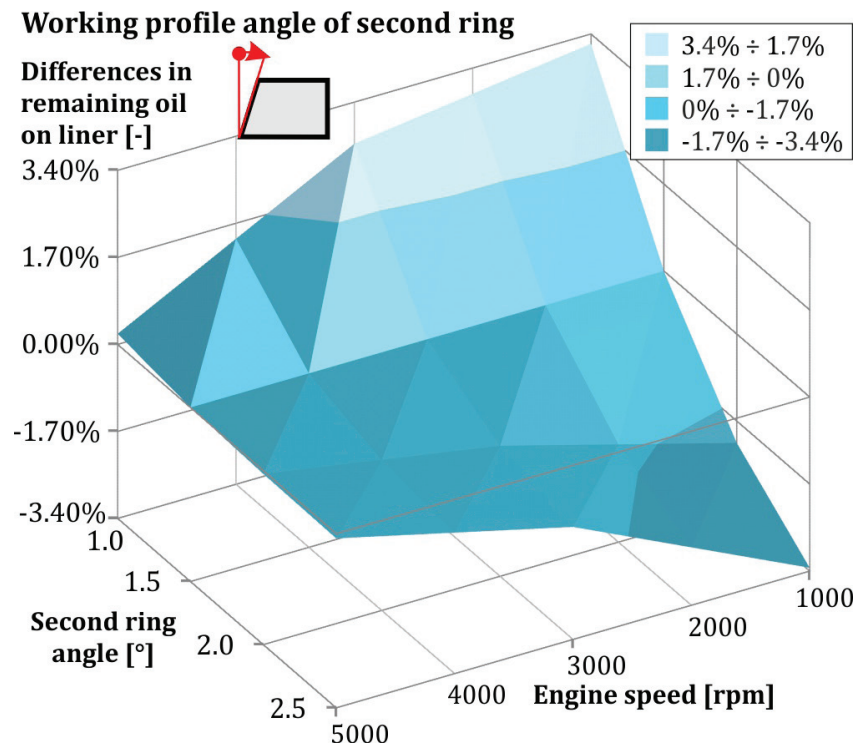

FIGURE 9: Influence of the working profile angle of the second piston ring on oil remaining on the liner

OBRÁZEK 9: Vliv úhlu pracovní plochy druhého kroužku na množství oleje ulpívajícího na vložce válce

This article thus presents a new and effective approach for solving the influence of parameters on the friction loss of piston rings within a certain range of values, as illustrated by selected results. This approach utilizes and further enhances the number of modern approaches by providing results suitable for the construction of new piston rings with lower friction losses for engines with lower fuel consumption and $\mathrm{CO}_{2}$ emissions.

\section{ACKNOWLEDGEMENT}

The results of this project titled NETME CENTRE PLUS (L01202), were achieved with financial support from the Ministry of Education, Youth and Sports of the Czech Republic under the program supporting research, experimental development and innovation: "National Sustainability Programme I." This support is gratefully acknowledged.

\section{REFERENCES}

[1] Novotný P., Pištěk V. (2011). Modelling of Piston Ring Dynamics, In: Journal of Middle European Construction and Design of Cars, Vol. 2011, No. 2, pp. 12 - 20. ISSN 1214-0821

[2] Heywood, J. B. Internal Combustion Engine Fundamentals, McGraw-Hill series in Mechanical Engineering, 1988

[3] Nakada, M. (1995). Piston and Piston Ring Tribology and Fuel Economy, In Proceedings of International Tribology Conference, Yokohama

[4] Tateishi, Y. (1994). Tribological Issues in Reducing Piston Ring Friction Losses, Tribology International, V27, No. 1 pp. $17-23$
[5] Andersson, P., Tamminen, J., Sandström, C. Piston ring tribology, VTT Research Notes 2178, 2002. ISBN 951-38-6107-4

[6] Macek, J. (2011) A Simple Physical Model of ICE Mechanical Losses, In: SAE Paper 2011-01-0610

[7] Novotný, P. and Píštěk V. (2010). New Efficient Methods for Powertrain Vibration Analysis. Proceedings of the Institution of Mechanical Engineers, Part D, Journal of Automobile Engineering, Vol.2010, No.224, pp. 611-629, ISSN 0954-4070

[8] Arcoumanis, C, Ostovar, P., and Mortier, R. (1997). Mixed Lubrication Modelling of Newtonian and Shear Thinning Liquids in a Piston-Ring Configuration, SAE Paper 972924

[9] Mufti, R. A., Priest, M. and Chittenden, R. J. (2008). Analysis of piston assembly friction using the indicated mean effective pressure experimental method to validate mathematical models. Proceedings of the Institution of Mechanical Engineers, Part D, Journal of Automobile Engineering. 222:1441, ISSN 0954-4070

[10] Wannatong, K. at al. (2008). Simulation Algorithm for Piston Ring Dynamics, In: Simulation Modelling Practice and Theory, pp. 127-146., ISSN 1569-190X

[11] Ortjohann, T. (2006). Simulation der Kolbenringdynamik auf der Basis expliziter FEM-Software, Dissetation, Aachen, SRN

[12] Kurbet, S. N., Krishna Kumar R. (2007). Finite element modelling of piston-ring dynamics and blow-by estimation in a four-cylinder diesel engine, In: Proceedings of the Institution of Mechanical Engineers, Part D, Journal of Automobile Engineering, 221:1405, ISSN 0954-4070

[13] Liu L. and Tian T. (2005). Modelling Piston Ring-Pack Lubrication With Consideration of Ring Structural Response, SAE Paper 2005-01-1641

[14] Scholz, B. and Bargende, M. (2000). Three-Dimensional Simulation of the Piston Group, SAE Paper 2005-01-1641

[15] Patir, N. and Cheng H. S. (1979). Application of Average Flow Model to Lubrication between Rough Sliding Surfaces. In: J. Lub Tech Trans. ASME, Serv. F, Vol. 101, pp. 220-230

[16] Patir, N., and Cheng, H. S. (1978). An Average Flow Model for Determining Effects of Three-Dimensional Roughness on Partial Hydrodynamic Lubrication, ASME Journal of Lubrication Technology, Vol. 100, pp. 12-17

[17] Greenwood, J. A., Tripp, J. H. (1970) The Contact of two Nominally Flat Rough Surfaces, In: Proc. Instn. Mech. Engrs., pp. 625-633, ISSN 0954-4100

[18] Maršálek, O., Novotný, P., Raffai, P. (2014), Microlubrication of Directionally Oriented Contact Surfaces, In: Tribology in Industry, Vol. 36, No. 4, p. 451-464. ISSN 0354-8996 